University of Nebraska - Lincoln

DigitalCommons@University of Nebraska - Lincoln

\title{
Characterization of biological types of cattle (Cycle VII): Influence of postpartum interval and estrous cycle length on fertility
}

\author{
R. A. Cushman \\ USDA-ARS, Bob.Cushman@ars.usda.gov \\ M. F. Allan \\ USDA-ARS \\ R. M. Thallman \\ USDA-ARS, Mark.Thallman@ars.usda.gov \\ L. V. Cundiff \\ USDA-ARS
}

Follow this and additional works at: https://digitalcommons.unl.edu/usdaarsfacpub

Part of the Agricultural Science Commons

Cushman, R. A.; Allan, M. F.; Thallman, R. M.; and Cundiff, L. V., "Characterization of biological types of cattle (Cycle VII): Influence of postpartum interval and estrous cycle length on fertility" (2007).

Publications from USDA-ARS / UNL Faculty. 806.

https://digitalcommons.unl.edu/usdaarsfacpub/806

This Article is brought to you for free and open access by the U.S. Department of Agriculture: Agricultural Research Service, Lincoln, Nebraska at DigitalCommons@University of Nebraska - Lincoln. It has been accepted for inclusion in Publications from USDA-ARS / UNL Faculty by an authorized administrator of DigitalCommons@University of Nebraska - Lincoln. 


\title{
Characterization of biological types of cattle (Cycle VII): Influence of postpartum interval and estrous cycle length on fertility ${ }^{1,2}$
}

\author{
R. A. Cushman, ${ }^{3}$ M. F. Allan, R. M. Thallman, and L. V. Cundiff \\ USDA, ARS, Roman L. Hruska US Meat Animal Research Center (USMARC), Clay Center, NE 68933-0166
}

\begin{abstract}
Genetic improvement in reproductive efficiency through selection is difficult because many reproductive traits are binomial and have low heritabilities. Before genetic markers can be generated for fertility in cows, greater characterization of reproductive phenotypes is needed to understand the components of the trait. The current study tested the hypotheses that: 1) breeds vary in postpartum interval to estrus (PPIE) and estrous cycle length, 2) a longer estrous cycle immediately before breeding increased pregnancy rates, and 3) a greater number of cycles before breeding increased conception rates. The postpartum interval to estrus, estrous cycle length, and number of cycles before breeding were examined in $F_{1}$ cows $(n=519)$ obtained from mating Hereford, Angus, and MARC III cows to Hereford, Angus, Simmental, Limousin, Charolais, Gelbvieh, and Red Angus sires. Cows were classified as having $0,1,2$, or 3 observed estrous cycles before breeding. All traits analyzed were adjusted to constant BCS. Sire breed of the cow influenced length of the PPIE and number of cycles before the start of breeding $(P<0.001)$. Simmental-sired cows had the shortest PPIE and greatest number of cycles before breeding, whereas Limou-
\end{abstract}

sin-sired cows had the longest PPIE and least number of cycles before breeding. Cows with a greater number of cycles before breeding did not have greater conception rates than cows that had not exhibited standing estrus before breeding $(P=0.87)$. In cows that cycled before breeding, the length of the estrous cycle immediately before breeding was influenced by dam breed and BCS $(P<0.01)$. Cows out of Hereford dams had shorter estrous cycles than cows out of MARC III or Angus dams, and estrous cycle length increased as BCS increased. Conception rate decreased as length of the estrous cycle immediately before breeding increased $(P=0.05,-2.2 \%$ per $\mathrm{d}$ of cycle length). Therefore, previously anestrous cows were just as likely to conceive as cows that had cycled before breeding, and an increased number of observed estrous cycles before breeding did not increase conception rates. There may be an influence of the length of estrous cycle immediately before breeding on conception rates, possibly because a longer estrous cycle results in a persistent follicle with greater potential for a lower quality oocyte. Breed differences in PPIE and estrous cycle length suggest that there are genetic components to these traits.

Key words: beef breed, postpartum interval, reproductive efficiency

(C2007 American Society of Animal Science. All rights reserved.

J. Anim. Sci. 2007. 85:2156-2162 doi:10.2527/jas.2007-0136

\section{INTRODUCTION}

Among commercial beef cattle producers, longevity of the breeding female has a major impact on profitability, and failure to become pregnant is the primary cause

\footnotetext{
${ }^{1}$ Names are necessary to report factually on available data; however, the USDA neither guarantees nor warrants the standard of the product, and the use of names by the USDA implies no approval of the product to the exclusion of others that may also be suitable.

${ }^{2}$ The authors gratefully acknowledge G. Hays and USMARC cattle operations for data collection and care of the animals and D. Light and L. Larsen for data management.

${ }^{3}$ Corresponding author: Bob.Cushman@ars.usda.gov

Received March 5, 2007.

Accepted May 8, 2007.
}

for a cow to leave the herd (Melton, 1995; Mathews and Short, 2001). Thus, development of both genetic markers and biomarkers for fertility would be of great economic benefit to commercial cattle producers; however, the low heritability and complex physiological pathways of reproductive traits make this a challenge requiring greater phenotypic information. A number of phenotypes have been linked to fertility in cows, including age at puberty (Lesmeister et al., 1973; Martin et al., 1992; Gargantini et al., 2005), postpartum interval (Short et al., 1990), length of the estrous cycle immediately before breeding (Ahmad et al., 1997; Townson et al., 2002), size of the ovulatory follicle (Perry et al., 2005, 2007; MacNeil et al., 2006), and the total number of follicles in the ovary (Maurer and Echternkamp, 1985; Cushman et al., 1999; Oliveira et al., 2002). 
At the US Meat Animal Research Center (USMARC), the Germplasm Evaluation (GPE) Program has historically evaluated breed differences for traits that are economically important to beef production. The objective of the current work was to evaluate breed differences in postpartum interval, numbers of cycles before breeding and length of the estrous cycle, and to determine their relationship to fertility in cows from Cycle VII of the GPE Program at 2 to $4 \mathrm{yr}$ of age. The hypotheses to be tested were 1) that breeds vary in postpartum interval to estrus and estrous cycle length, 2) that a longer estrous cycle immediately before breeding would be associated with increased fertility, and 3) that an increased number of observed standing estruses before breeding would be associated with increased fertility.

\section{MATERIALS AND METHODS}

\section{Cows and Data Collection}

All animal procedures were approved by the USMARC Animal Care and Use Committee.

The breeds represented in Cycle VII of the GPE Program are those with the largest registration numbers in their respective breed registries in the United States (Wheeler et al., 2005): Angus, Hereford, Gelbvieh, Charolais, Limousin, Red Angus, and Simmental. Approximately one-half of the sires represented the 50 most popular sires within a breed based on registrations, whereas the remaining one-half represented unproven younger sires. Semen from these sires was used to artificially inseminate Angus, Hereford, or composite MARC III (1/4 Angus, $1 / 4$ Hereford, $1 / 4$ Pinzgauer, and 1/4 Red Poll) dams. Heifers $(\mathrm{n}=519)$ produced by these crosses were born in 1999 and 2000. Management practices at USMARC are for the heifers to be bred early so that they calve early as 2-yr-olds and have a longer recovery period before rebreeding. Therefore, heifers were exposed to bulls for $63 \mathrm{~d}$ beginning on 10 May 2000 and for $61 \mathrm{~d}$ beginning on 21 May 2001. Heifers born in 1999 produced their first calves between 8 February and 24 April 2001, and those born in 2000 produced their first calves between 13 February and 2 May 2002.

Postpartum cows of all 3 age groups were fed ad libitum a ration consisting of $70 \%$ corn silage and $30 \%$ alfafa haylage, starting as soon after calving as possible. Beginning approximately $35 \mathrm{~d}$ after the first cow calved at 2, 3, and $4 \mathrm{yr}$ of age, teaser bulls were placed with the cows and behavioral estrus was checked twice daily at 0600 and 1630 until the start of the breeding season, when fertile bulls were placed with the cows around the first week of June. Cows were evaluated for BCS before the start of the breeding season at $59.9 \pm$ $0.6 \mathrm{~d}$ postpartum, and twice daily checks for behavioral estrus were continued through the first month of the breeding season. Because breeding continued for another $30 \mathrm{~d}$ after detection of estrus was completed, con-
Table 1. Records eliminated from observed estrous cycle number and cycle length analyses and the reason for elimination

\begin{tabular}{lr}
\hline \hline Description & PPIE $^{1}$ \\
\hline Starting records & 1,429 \\
No PPIE & -74 \\
No records after first estrus & -153 \\
No records after first cycle & -122 \\
No records after second cycle & -92 \\
No records after third cycle & -25 \\
Prebreeding estrous cycle < 17 d & -59 \\
Prebreeding estrous cycle $>24$ d & -111 \\
Culled before calving & -8 \\
More than 3 estrous cycles & -24 \\
Records used & 761 \\
\hline
\end{tabular}

${ }^{1} \mathrm{PPIE}=$ postpartum interval to estrus.

ception to an observed mating was confirmed by the subsequent calving date being $\leq 300 \mathrm{~d}$ from the observed mating.

A total of 1,355 postpartum intervals were generated from 2001 to 2004 , for which a calving date and estrous behavior were both observed. There were 74 instances in which a cow was not observed in estrus during the period of observation. In those instances, the maximum observed postpartum interval to estrus (PPIE) of 121 $d$ was used to reduce the bias in estimated effects that would otherwise occur due to censoring of unobserved PPIE records. Therefore, the total number of records included in the analysis of PPIE was 1,429. For determination of the influence of number of estrous cycles and the length of the estrous cycle, which ended with the first observed estrus in the breeding season, data were censored as shown in Table 1.

Briefly, 392 records were eliminated when cows showed behavioral estrus once or more before the breeding season, but there were no records that extended into the breeding season; 170 records were eliminated due to the length of the estrous cycle immediately before breeding being outside the normal range (17 to $24 \mathrm{~d}$ ); 8 records were eliminated because the cows were culled before calving and conception to breeding could not be confirmed by gestation length; and 24 records were eliminated due to a high frequency of behavioral estrus (cystic). This resulted in 761 records with between 0 and 3 estrous cycles before the start of breeding and an estrous cycle length immediately before breeding of 17 to $24 \mathrm{~d}$. In cows with 2 or 3 estrous cycles, the lengths of the estrous cycles before the estrous cycle of interest were not censored. The length of the first estrous cycle in cows with 2 or 3 estrous cycles was $19.6 \pm 0.4 \mathrm{~d}$, and the length of the second estrous cycle in cows with 3 estrous cycles was $20.1 \pm 0.1 \mathrm{~d}$.

\section{Statistical Analyses}

Postpartum interval to estrus was analyzed by the MIXED procedure (SAS Institute Inc., Cary, NC), with a model that included Julian day of calving and BCS 


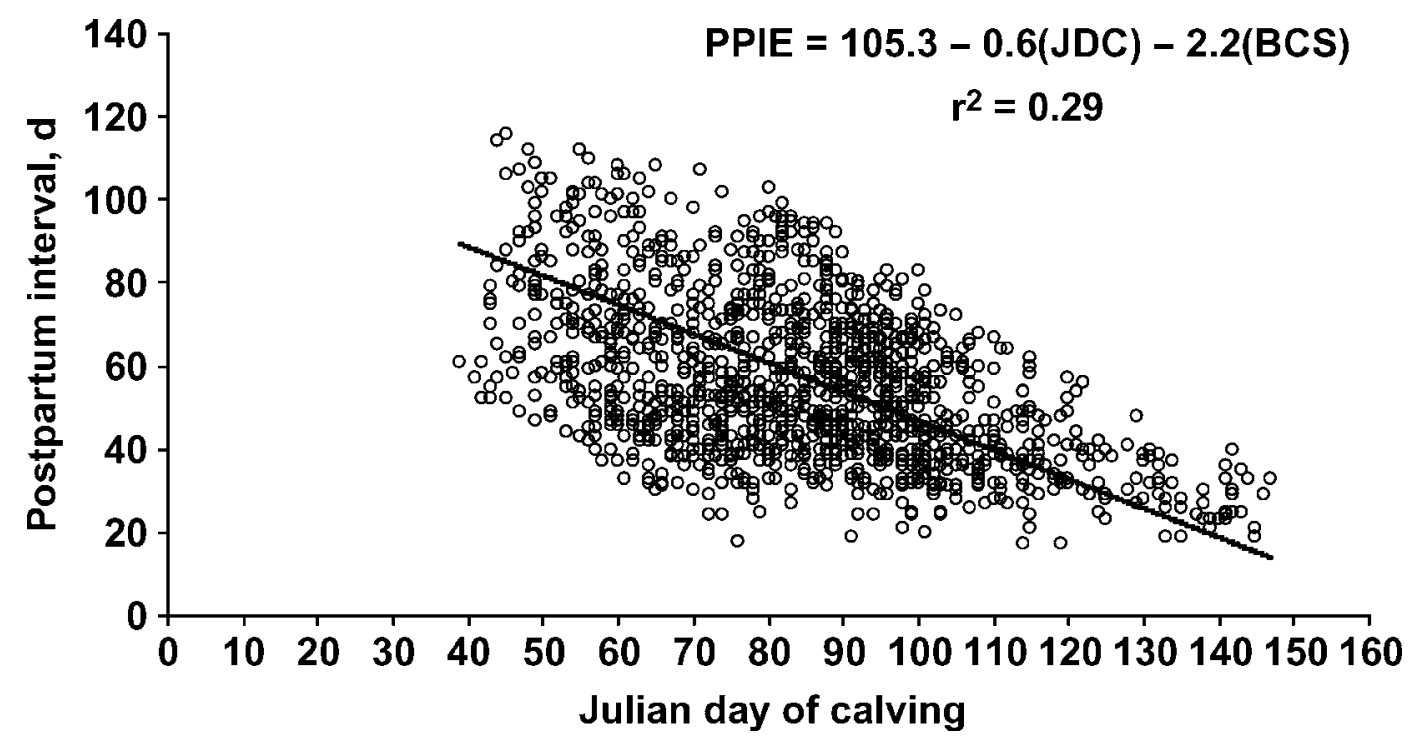

Figure 1. Influence of Julian day of calving (JDC) on postpartum interval to estrus (PPIE; $n=1355$ ) in Germplasm Evaluation Cycle VII cows. As the JDC and BCS increased, the PPIE decreased $(P<0.0001)$.

as linear effects; year, age, sire breed, dam breed, and all appropriate interactions as fixed effects; and sire nested within sire breed, dam nested within dam breed, the interaction of sire and dam, and animal nested within the interaction of sire and dam as random effects.

The number of cycles before breeding and length of the estrous cycle immediately before breeding were analyzed using the MIXED procedure of SAS, with a model that included the fixed effects of year, age, BCS, sire breed, dam breed, and all appropriate interactions, with sire nested within sire breed, dam nested within dam breed, the interaction of sire and dam, and animal nested within the interaction of sire and dam as random effects. Conception rate, defined as the proportion of cows that conceived to first observed estrus during the breeding season and confirmed by subsequent calving date, was analyzed using the MIXED procedure of SAS, with a model that included the fixed effects of year, age, BCS, number of cycles, sire breed, dam breed, and all appropriate interactions, with sire nested within sire breed, dam nested within dam breed, the interaction of sire and dam, and animal nested within the interaction of sire and dam as random effects.

The influence of estrous cycle length before breeding on conception rate was analyzed using the MIXED procedure of SAS, with a model that included the fixed effects of year, age, BCS, estrous cycle length, sire breed, dam breed, and all appropriate interactions, with sire nested within sire breed, dam nested within dam breed, the interaction of sire and dam, and animal nested within the interaction of sire and dam as random effects. For all models, when significance was indicated for a fixed effect $(P<0.05)$, a means separation was performed using the PDIFF option of LSMEANS.

\section{RESULTS}

Statistical analyses revealed no significant interactions of fixed effects; therefore, discussion of results is limited to main effects. The length of the PPIE was influenced by age, the Julian day of the year that a cow calved, BCS, and sire breed. As Julian day of calving or BCS increased, postpartum interval decreased $(P<$ 0.0001; Figure 1). Whereas the average Julian day of the year that cows calved did not differ among sire breeds, there were effects of sire breed on length of the postpartum interval $(P<0.0001$, Table 2$)$; PPIE was shortest in the Simmental-sired cows and longest in the Limousin-sired cows (Table 3). The Simmentalsired cows that had the shortest postpartum interval also had the greatest number of cycles before breeding, and the Limousin-sired cows that had the longest postpartum interval had the least number of cycles before breeding. Gestation length was also influenced by sire breed because cows sired by Limousin bulls had a longer gestation length than other breeds $(P=0.001$, Table 3$)$.

Table 2. Effect of sire breed on postpartum reproductive phenotypes

\begin{tabular}{lcccc}
\hline \hline Sire breed & Sires & Records & PPIE, ${ }^{1} d$ & BCS \\
\hline Hereford & 21 & 180 & $61.2 \pm 2.4^{\mathrm{ab}}$ & $6.4 \pm 0.1^{\mathrm{ab}}$ \\
Angus & 21 & 176 & $62.9 \pm 2.1^{\mathrm{a}}$ & $6.3 \pm 0.1^{\mathrm{ab}}$ \\
Simmental & 20 & 214 & $55.5 \pm 2.2^{\mathrm{b}}$ & $6.2 \pm 0.1^{\mathrm{b}}$ \\
Limousin & 20 & 212 & $66.7 \pm 2.1^{\mathrm{a}}$ & $6.1 \pm 0.1^{\mathrm{b}}$ \\
Charolais & 22 & 211 & $62.6 \pm 2.0^{\mathrm{ab}}$ & $6.3 \pm 0.1^{\mathrm{ab}}$ \\
Gelbvieh & 21 & 215 & $57.5 \pm 2.1^{\mathrm{b}}$ & $5.9 \pm 0.1^{\mathrm{c}}$ \\
Red Angus & 21 & 221 & $60.8 \pm 2.2^{\mathrm{ab}}$ & $6.5 \pm 0.1^{\mathrm{a}}$ \\
\hline
\end{tabular}

${ }^{\mathrm{a}-\mathrm{c}}$ Within a column, means with different superscripts $\operatorname{differ}, P<$ 0.004 .

${ }^{1} \mathrm{PPIE}=$ postpartum interval to estrus, adjusted to constant BCS. 
Table 3. Effect of sire breed on number of estrous cycles observed between calving and breeding

\begin{tabular}{lccccc}
\hline \hline Sire breed & Sires & Records & $\begin{array}{c}\text { Observed cycles } \\
\text { before breeding }\end{array}$ & $\begin{array}{c}\text { Conception } \\
\text { rate }^{1}\end{array}$ & $\begin{array}{c}\text { Gestation } \\
\text { length, d }\end{array}$ \\
\hline Hereford & 21 & 93 & $1.1 \pm 0.1^{\mathrm{b}}$ & $75.3 \pm 6.5$ & $285.5 \pm 1.2^{\mathrm{a}}$ \\
Angus & 21 & 92 & $1.1 \pm 0.1^{\mathrm{b}}$ & $73.2 \pm 5.3$ & $284.1 \pm 0.9^{\mathrm{a}}$ \\
Simmental & 20 & 119 & $1.6 \pm 0.1^{\mathrm{c}}$ & $82.7 \pm 5.5$ & $284.8 \pm 0.9^{\mathrm{a}}$ \\
Limousin & 20 & 120 & $0.9 \pm 0.1^{\mathrm{b}}$ & $71.5 \pm 5.2$ & $287.0 \pm 0.9^{\mathrm{b}}$ \\
Charolais & 22 & 117 & $1.1 \pm 0.1^{\mathrm{b}}$ & $79.1 \pm 5.0$ & $284.2 \pm 0.8^{\mathrm{a}}$ \\
Gelbvieh & 21 & 117 & $1.2 \pm 0.1^{\mathrm{b}}$ & $74.1 \pm 5.4$ & $286.1 \pm 0.9^{\mathrm{b}}$ \\
Red Angus & 21 & 103 & $1.2 \pm 0.1^{\mathrm{b}}$ & $79.5 \pm 5.8$ & $283.4 \pm 0.9^{\mathrm{a}}$ \\
\hline
\end{tabular}

${ }^{\mathrm{a}-\mathrm{c}}$ Within a column, means with different superscripts differ, $P<0.004$.

${ }^{1}$ Adjusted to constant BCS.

Although sire breeds differed in the number of estrous cycles before breeding, the number of estrous cycles before mating did not influence conception rates $(P=0.87$, Table 4$)$; cows that showed no signs of estrus before mating were just as likely to conceive to natural service as cows that had one or more observed estrous cycles before mating. There were no differences in day of the year of the previous calving $(P=0.35,85.2 \pm 1.2$ vs. $84.2 \pm 1.6)$ or PPIE $(P=0.31,57.4 \pm 1.7$ vs. $55.9 \pm$ $13 \mathrm{~d})$ between cows that conceived to natural service and cows that did not conceive to natural service, respectively. Furthermore, there was no difference in average day of conception between cows that had not cycled previously and cows that had cycled previously (Table 4). There was an influence of age on PPIE and the number of cycles before breeding. Two-year-old cows that were managed to calve earlier had a shorter PPIE and more cycles before breeding than 3- and 4-yr-old cows $(P<0.0001$; Table 5). Body condition score increased as cows aged $(P=0.01)$.

The length of the estrous cycle immediately before breeding did not influence conception rates $(P=0.27$; Table 6) when analyzed as a fixed effect; however, when estrous cycle length was analyzed as a linear effect, the regression of estrous cycle length on conception rate showed a decrease in conception rate as estrous cycle length increased $(P=0.05,-2.2 \%$ per $\mathrm{d}$ of estrous cycle length). Dam breed influenced cycle length $(P=0.0002$; Table 7); the cows born to Hereford dams had the shortest estrous cycle length, the cows born to Angus dams

Table 4. Effect of numbers of observed estrous cycles before breeding on pregnancy rate and day of conception in Germplasm Evaluation Cycle VII cows

\begin{tabular}{lccc}
\hline $\begin{array}{l}\text { Number of } \\
\text { observed } \\
\text { estrous cycles }\end{array}$ & Records & $\begin{array}{c}\text { Conception } \\
\text { rate }\end{array}$ & $\begin{array}{c}\text { Julian } \\
\text { day of } \\
\text { conception }\end{array}$ \\
\hline 0 & 232 & $75.7 \pm 4.1$ & $170.8 \pm 3.0$ \\
1 & 274 & $75.7 \pm 3.7$ & $169.3 \pm 0.5$ \\
2 & 193 & $74.5 \pm 4.2$ & $171.7 \pm 0.7$ \\
3 & 62 & $79.9 \pm 6.3$ & $172.1 \pm 0.8$ \\
\hline
\end{tabular}

${ }^{1}$ Confirmed by calving date. had the longest estrous cycle length, and the cows born to MARC III dams had an intermediate estrous cycle length. Body condition score also influenced cycle length $(P=0.003$, Table 8$)$ such that estrous cycle length increased as BCS increased.

\section{DISCUSSION}

The results of the current study support our primary hypothesis that there are breed differences in PPIE and the length of the estrous cycle immediately before breeding. The effects of PPIE on reproductive efficiency were reviewed extensively (Short et al., 1990), and it was proposed that cows that cycled earlier had more estrous cycles before breeding, which resulted in improved fertility (Thatcher and Wilcox, 1973). In the current study, the 2-yr-old cows were managed to calve earlier because previous work has demonstrated that first parity cows require a longer time to resume estrous cycles postpartum (Wiltbank and Cook, 1958). However, the 2-yr-old cows had a shorter average PPIE than 3 - and 4-yr-old cows. This shorter PPIE resulted in an increased number of estrous cycles before breeding but no difference in first service conception rates. This increased number of estrous cycles before breeding in the 2-yr-old cows indicates that the shorter PPIE is real, resulting in onset of regular estrous cycles and not due to spurious estrous behavior without ovulation. The collection of the superior phenotype of serum progesterone may have given a different result, or these differences could be related to differences between beef and dairy breeds of cattle, because the previous reports were from studies with dairy cows.

In support of this, in a recent study examining Friesian $\times$ Jersey crosses in a seasonal dairy production system in New Zealand, cows that had 2 or more cycles before breeding had greater first service conception rates to AI than cows with 0 or 1 cycle before breeding (McNaughton et al., 2007). However, in the current study, whereas breeds that cycled earlier had an increased number of observed estrous cycles before breeding, this did not result in a statistically significant increase in conception rates or in an earlier day of conception. This discrepancy may be due to a lack of power 
Table 5. Influence of age on reproductive phenotypes in Germplasm Evaluation Cycle VII cows

\begin{tabular}{lcccccc}
\hline \hline $\begin{array}{l}\text { Age, } \\
\text { yr }\end{array}$ & Records & $\begin{array}{c}\text { Julian } \\
\text { day of } \\
\text { calving }\end{array}$ & PPIE $^{2}$ & $\begin{array}{c}\text { Observed } \\
\text { cycles }\end{array}$ & BCS & $\begin{array}{c}\text { Conception } \\
\text { rate }^{3}\end{array}$ \\
\hline 2 & 215 & $71.2 \pm 0.7^{\mathrm{a}}$ & $55.3 \pm 1.2^{\mathrm{a}}$ & $1.5 \pm 0.1^{\mathrm{a}}$ & $6.1 \pm 0.1^{\mathrm{a}}$ & $82.8 \pm 4.1$ \\
3 & 356 & $91.6 \pm 0.8^{\mathrm{b}}$ & $65.4 \pm 1.3^{\mathrm{b}}$ & $0.9 \pm 0.1^{\mathrm{b}}$ & $6.3 \pm 0.1^{\mathrm{b}}$ & $78.8 \pm 3.9$ \\
4 & 190 & $95.7 \pm 1.3^{\mathrm{c}}$ & $62.4 \pm 2.2^{\mathrm{b}}$ & $1.0 \pm 0.1^{\mathrm{b}}$ & $6.5 \pm 0.1^{\mathrm{c}}$ & $72.8 \pm 5.1$ \\
\hline
\end{tabular}

${ }^{\mathrm{a}-\mathrm{c}}$ Within a column, means with different superscripts differ, $P<0.01$.

${ }^{1}$ Day of the year on which calving occurred.

${ }^{2} \mathrm{PPIE}=$ postpartum interval to estrus.

${ }^{3}$ Conception rate to first observed fertile mating, confirmed by gestation length.

or to the use of blood progesterone concentrations to determine luteal activity in the previous study compared with the detection of behavioral estrus in the current study. The first ovulation postpartum is associated with a silent estrus in the majority of cows (Menge et al., 1962; Ciccioli et al., 2003). Therefore, serum progesterone concentrations may be a better indicator of PPIE and of fertility in the postpartum beef cow than estrous behavior. However, using visual detection of estrus, Thatcher and Wilcox (1973) observed a decline in services required per pregnancy as the number of observed estruses increased in dairy cows. Thus, it is more likely that the observed differences between the current study and previous work are due to differences between beef and dairy cows.

Length of the postpartum interval was influenced by age, Julian day of calving, BCS, and sire breed. Julian day of the year and BCS could be mediators of seasonal effects on PPIE because as the day of year progresses toward the summer solstice, the postpartum interval decreases. A number of authors have addressed the causes of this decrease in PPIE as the day of year advances (Short et al., 1990; Roberts et al., 2005), and suggested that it was due to increasing day length or increasing availability of nutrients. In truth, both of these factors likely influence the length of PPIE in cows. Recently, we and others have demonstrated evidence of clock genes expressed in peripheral tissues, including

Table 6. Effect of length of the estrous cycle immediately before breeding on conception rate in Germplasm Evaluation Cycle VII cows

\begin{tabular}{lcc}
\hline \hline $\begin{array}{l}\text { Cycle } \\
\text { length, d }\end{array}$ & Records & $\begin{array}{c}\text { Conception } \\
\text { rate }^{1}\end{array}$ \\
\hline 17 & 10 & $81.0 \pm 13.3$ \\
18 & 39 & $84.5 \pm 7.7$ \\
19 & 110 & $77.5 \pm 5.2$ \\
20 & 138 & $84.9 \pm 5.2$ \\
21 & 82 & $74.6 \pm 5.8$ \\
22 & 81 & $77.8 \pm 5.9$ \\
23 & 40 & $73.2 \pm 8.0$ \\
24 & 29 & $62.5 \pm 8.6$ \\
\hline
\end{tabular}

${ }^{1}$ Conception rate to first observed fertile mating, confirmed by gestation length. the ovary (Cushman et al., 2007). The level of transcription of clock genes is influenced by nutritional status (Yang et al., 2006), immunological status, and day length (Dahl et al., 2002; Lincoln et al., 2003; Boden and Kennaway, 2006). Therefore, initiation of postpartum estrous cycles and fertility could be related to an overall state of physiological well-being, indicating that the season, nutrient supply, and health status of the female are such that the time to reproduce is ideal.

There was an influence of sire breed on PPIE and the number of cycles before breeding. Simmental-sired cows had the shortest PPIE and the most observed estrous cycles before breeding, whereas Limousin-sired cows had the longest PPIE and the fewest observed estrous cycles before breeding. This further supports that the censoring of the data for cycle numbers and cycle length was performed appropriately and suggests that there may be breed differences in seasonal response to nutrient level and day length, which control the length of postpartum anestrus. A heritability for the length of postpartum anestrus of between 0.11 and 0.38 was reported in Charolais cows, depending upon whether visual detection of behavioral estrus or serum progesterone concentrations were used to determine cycling status (Mialon et al., 2000). Clearly, there are genetic components to postpartum anestrus that should be investigated further to understand how some breeds begin to cycle earlier before the start of the breeding season. Although we have shown no direct connection between PPIE, increased numbers of estrous cycles, and increased fertility, others have (Thatcher and Wilcox, 1973; McNaughton et al., 2007), and only by better understanding the components of fertility can we hope to make any true progress in the genetics of reproductive efficiency of cattle.

The breed effects estimated here for all traits were adjusted to a common BCS. This is a useful approach from the perspective of partitioning the components of fertility. However, the breeds may differ in BCS. It must be emphasized that the economically important trait is pregnancy rate unadjusted for BCS. It is possible that the breed differences in pregnancy rate would have been statistically significant in this data set had BCS been omitted from the model. 
Table 7. Influence of dam breed on the length of the estrous cycle immediately before breeding

\begin{tabular}{lccccc}
\hline \hline Dam breed & Dams & Records & $\begin{array}{c}\text { Cycle } \\
\text { length, d }\end{array}$ & $\begin{array}{c}\text { Conception } \\
\text { rate }^{1}\end{array}$ & BCS \\
\hline Hereford & 71 & 90 & $19.7 \pm 0.3^{\mathrm{a}}$ & $75.8 \pm 5.2$ & $6.5 \pm 0.1^{\mathrm{a}}$ \\
Angus & 157 & 179 & $20.7 \pm 0.2^{\mathrm{c}}$ & $75.9 \pm 4.0$ & $6.2 \pm 0.1^{\mathrm{b}}$ \\
MARC III & 214 & 260 & $20.4 \pm 0.2^{\mathrm{b}}$ & $77.7 \pm 3.3$ & $6.0 \pm 0.1^{\mathrm{c}}$ \\
\hline
\end{tabular}

${ }^{\mathrm{a}-\mathrm{c}}$ Within a column, means with different superscript letters differ, $P<0.001$.

${ }^{1}$ Conception rate to first observed fertile mating, confirmed by gestation length.

We further investigated the influence of the length of the estrous cycle immediately before breeding on conception rates in cows from GPE Cycle VII. Townson et al. (2002) suggested a positive relationship between length of the estrous cycle immediately before breeding and fertility in Holstein cows. Their reasoning for this was that cows with 3 waves of follicular development had longer estrous cycles than cows with 2 waves, and 3 waves of follicular development were associated with increased conception rates. This was proposed to be due to the ovulation of younger follicles with oocytes of greater quality in 3-wave compared with 2 -wave estrous cycles. Similar results were observed in beef cows (Ahmad et al., 1997); however, a recent study reported no difference in fertility between Brown Swiss cows with 2 or 3 waves of follicular development before mating (Celik et al., 2005). In the current study, there was no increase in fertility in cows having a longer estrous cycle immediately before breeding, and in fact, conception rates were lower when the estrous cycle was longer. Investigators have identified a polymorphism of the human FSH receptor gene, which was associated with increased menstrual cycle length (Greb et al., 2005) and decreased fertility (Jun et al., 2006). Therefore, it is conceivable that longer estrous cycles result in prolonged follicle growth before ovulation and decreased quality of the oocytes that are ovulated.

Cows born to Hereford dams had a shorter estrous cycle length than the cows born to Angus or MARC III dams. A previous report (Lamond et al., 1971) identified this difference in estrous cycle length between Angus and Hereford cows. Estrous cycle length was determined by collecting daily blood samples for analysis of serum progesterone concentrations, and the investiga-

Table 8. Influence of body condition score on estrous cycle length

\begin{tabular}{lcc}
\hline \hline $\begin{array}{l}\text { Body } \\
\text { condition } \\
\text { score }\end{array}$ & Records & $\begin{array}{c}\text { Estrous cycle } \\
\text { length, d }\end{array}$ \\
\hline 4 & 13 & $19.2 \pm 0.5^{\mathrm{a}}$ \\
5 & 97 & $20.1 \pm 0.2^{\mathrm{b}}$ \\
6 & 240 & $20.4 \pm 0.1^{\mathrm{b}}$ \\
7 & 150 & $20.3 \pm 0.2^{\mathrm{b}}$ \\
8 & 29 & $21.3 \pm 0.3^{\mathrm{c}}$ \\
\hline
\end{tabular}

${ }^{\mathrm{a}-\mathrm{c}}$ Means with different superscripts differ, $P<0.01$. tors reported that this difference in estrous cycle length was due primarily to a longer follicular phase in the Angus cows. This genetic difference in the length of the period when the ovulatory follicle is in its final stages of growth could explain differences in the response to hormones for synchronization of estrus and may explain differences in fertility. However, cows born to Hereford dams had estrous cycles that were shorter on average, and this did not result in increased conception rates among cows from Hereford dams. This does not support our finding that shorter estrous cycles are more fertile. Taken together, these results may indicate that estrous cycle length alone or ovulatory follicle size alone is not the best phenotype for predicting fertility. Perhaps the length of the estrous cycle in combination with the size of the ovulatory follicle is the best indicator trait of the fertility of a given mating, in lieu of the intensive labor required to follow individual follicular waves by daily ultrasound scans.

Estrous cycle length was also influenced by BCS; cows with low BCS had the shortest estrous cycle lengths, whereas cows with high BCS had estrous cycles that were on average $2 \mathrm{~d}$ longer. These results should be interpreted cautiously because of the low numbers of thin and fat cows in this study. This could suggest impaired luteal function and a reduced window of opportunity for recognition of pregnancy to occur; however, low BCS did not decrease conception rates, possibly due to improved conception rates associated with shorter estrous cycles. Clearly, there are antagonistic forces at work emphasizing the redundancy of the mechanisms controlling reproduction due to its importance for maintenance and propagation of the species. Further research is needed to understand the environmental and genetic components influencing estrous cycle length and the influence of estrous cycle length before breeding on fertility in cattle.

Increasing the number of observed estrous cycles before breeding did not positively influence fertility in postpartum beef cows. Therefore, the mechanism by which decreased postpartum anestrus improves fertility may be more due to positive seasonal effects of day length and nutrient level on the reproductive axis than to increased cycle numbers. Extended estrous cycle lengths may be associated with persistent follicles and result in the ovulation of lesser quality oocytes with reduced chance of supporting early embryonic develop- 
ment. Differences among breeds in PPIE and estrous cycle length indicate genetic components of these traits.

\section{LITERATURE CITED}

Ahmad, N., E. C. Townsend, R. A. Dailey, and E. K. Inskeep. 1997. Relationships of hormonal patterns and fertility to occurrence of two or three waves of ovarian follicles, before and after breeding, in beef cows and heifers. Anim. Reprod. Sci. 49:13-28.

Boden, M. J., and D. J. Kennaway. 2006. Circadian rhythms and reproduction. Reproduction 132:379-392.

Celik, H. A., I. Aydin, S. Sendag, and D. A. Dinc. 2005. Number of follicular waves and their effect on pregnancy rate in the cow. Reprod. Domest. Anim. 40:87-92.

Ciccioli, N. H., R. P. Wettemann, L. J. Spicer, C. A. Lents, F. J. White, and D. H. Keisler. 2003. Influence of body condition score at calving and postpartum nutrition on endocrine function and reproductive performance of primiparous beef cows. J. Anim. Sci. 81:3107-3120.

Cushman, R. A., M. F. Allan, S. A. Jones, G. P. Rupp, and S. E. Echternkamp. 2007. Localization of Period 1 mRNA in the ruminant oocyte and investigations of its role in ovarian function. Anim. Reprod. Sci. 99:93-105.

Cushman, R. A., J. C. DeSouza, V. S. Hedgpeth, and J. H. Britt. 1999. Superovulatory response of one ovary is related to the microand macroscopic population of follicles in the contralateral ovary of the cow. Biol. Reprod. 60:349-354.

Dahl, G. E., T. L. Auchtung, and P. E. Kendall. 2002. Photoperiodic effects on endocrine and immune function in cattle. Reprod. Suppl. 59:191-201.

Gargantini, G., L. V. Cundiff, D. D. Lunstra, and L. D. van Vleck. 2005. Genetic relationships between male and female reproductive traits in beef cattle. Prof. Anim. Sci. 21:195-199.

Greb, R. R., K. Grieshaber, J. Gromoll, B. Sonntag, E. Nieschlag, L. Kiesel, and M. Simoni. 2005. A common single nucleotide polymorphism in exon 10 of the human follicle stimulating hormone receptor is a major determinant of length and hormonal dynamics of the menstrual cycle. J. Clin. Endocrinol. Metab. 90:4866-4872.

Jun, J. K., J. S. Yoon, S. Y. Ku, Y. M. Choi, K. R. Hwang, S. Y. Park, G. H. Lee, W. D. Lee, S. H. Kim, J. G. Kim, and S. Y. Moon. 2006. Follicle-stimulating hormone receptor gene polymorphism and ovarian responses to controlled ovarian hyperstimulation for IVF-ET. J. Hum. Genet. 51:665-670.

Lamond, D. R., D. M. Henricks, J. R. Hill, Jr., and J. F. Dickey. 1971. Breed differences in plasma progesterone concentration in the bovine during proestrus. Biol. Reprod. 5:258-261.

Lesmeister, J. L., P. J. Burfening, and R. L. Blackwell. 1973. Date of first calving in beef cows and subsequent calf production. J. Anim. Sci. 73:1-6.

Lincoln, G. A., H. Andersson, and A. Loudon. 2003. Clock genes in calendar cells as the basis of annual timekeeping in mammalsa unifying hypothesis. J. Endocrinol. 179:1-13.

MacNeil, M. D., T. W. Geary, G. A. Perry, A. J. Roberts, and L. J. Alexander. 2006. Genetic partitioning of variation in ovulatory follicle size and probability of pregnancy in beef cattle. J. Anim. Sci. 84:1646-1650.

Martin, L. C., J. S. Brinks, R. M. Bourdon, and L. V. Cundiff. 1992. Genetic effects on beef heifer puberty and subsequent reproduction. J. Anim. Sci. 70:4006-4017.
Mathews, K. H., and S. D. Short. 2001. The beef cow replacement decision. J. Agribusiness 19:191-211.

Maurer, R. R., and S. E. Echternkamp. 1985. Repeat-breeder females in beef cattle: Influences and causes. J. Anim. Sci. 61:624-636.

McNaughton, L. R., K. M. Sanders, J. E. Pryce, G. E. Bracefield, S. J. Harcourt, and R. J. Spelman. 2007. Phenotypic relationships between the interval from calving to first luteal activity and fertility in a seasonal dairy production system. Anim. Reprod. Sci. doi:10.1016/j.anirepro.sci.2006.10.014

Melton, B. F. 1995. Conception to consumption: The economics of genetic improvement. Pages 40-47 in Proc. Beef Improve. Fed. 27th Res. Symp. Annu. Meet., Sheridan, WY.

Menge, A. C., S. E. Mares, W. J. Tyler, and L. E. Casida. 1962. Variation and association among postpartum reproduction and production characteristics in Holstein-Friesian cattle. J. Dairy Sci. 45:233-241.

Mialon, M. M., G. Renand, D. Krauss, and F. Menissier. 2000. Genetic variability of the length of postpartum anoestrus in Charolais cows and its relationship with age at puberty. Genet. Sel. Evol. 32:403-414.

Oliveira, J. F. C., J. P. Neves, J. C. F. Moraes, P. B. D. Goncalves, J. M. Bahr, A. G. Hernandez, and L. F. S. Costa. 2002. Follicular development and steroid concentrations in cows with different levels of fertility raised under nutritional stress. Anim. Reprod. Sci. 73:1-10.

Perry, G. A., M. F. Smith, M. C. Lucy, J. A. Green, T. E. Parks, M. D. MacNeil, A. J. Roberts, and T. W. Geary. 2005. Relationship between follicle size at insemination and pregnancy success. Proc. Natl. Acad. Sci. USA 102:5268-5273.

Perry, G. A., M. F. Smith, A. J. Roberts, M. D. MacNeil, and T. W. Geary. 2007. Relationship between size of the ovulatory follicle and pregnancy success in beef heifers. J. Anim. Sci. 85:684-689.

Roberts, A. J., J. Klindt, and T. G. Jenkins. 2005. Effects of varying energy intake and sire breed on duration of postpartum anestrus, insulin like growth factor-1, and growth hormone in mature crossbred cows. J. Anim. Sci. 83:1705-1714.

Short, R. E., R. A. Bellows, R. B. Staigmiller, J. G. Berardinelli, and E. E. Custer. 1990. Physiological mechanisms controlling anestrus and infertility in postpartum beef cattle. J. Anim. Sci. 68:799-816.

Thatcher, W. W., and C. J. Wilcox. 1973. Postpartum estrus as an indicator of reproductive status in the cow. J. Dairy Sci. 56:608-610.

Townson, D. H., P. C. W. Tsang, W. R. Butler, M. Frajblat, L. C. Griel, Jr., C. J. Johnson, R. A. Milvae, G. M. Niksic, and J. L. Pate. 2002. Relationship of fertility to ovarian follicular waves before breeding in dairy cows. J. Anim. Sci. 80:1053-1058.

Wheeler, T. L., L. V. Cundiff, S. D. Shackelford, and M. Koohmaraie. 2005. Characterization of biological types of cattle (Cycle VII): Carcass, yield, and longissimus palatability traits. J. Anim. Sci. 83:196-207.

Wiltbank, J. N., and A. C. Cook. 1958. The comparative reproductive performance of nursed cows and milked cows. J. Anim. Sci. 17:640-648.

Yang, X., M. Downes, R. T. Yu, A. L. Bookout, W. He, M. Straume, D. J. Mangelsdorf, and R. M. Evans. 2006. Nuclear receptor expression links the circadian clock to metabolism. Cell 126:801-810. 